\title{
SURGICAL INCISION TECHNIQUE APPROACH ON DISTAL FEMUR FRACTURE A LITERATURE REVIEW
}

\author{
Rudiansyah Harahap ${ }^{1}$, Ferlyannisa Ikanandia ${ }^{2}$ \\ ${ }^{1}$ Orthopaedic surgeon, Medical Faculty of Semarang Muhammadiyah University \\ ${ }^{2}$ Tugurejo Semarang Hospital
}

\begin{abstract}
Fractures of the distal femur is described as a classic fragility fracture. Distal Femur fractures are rare, with a prevalence of $0.5 \%$ of all fractures. The incidence of distal femur fractures is $8.7 / 100,000$ /year. After the age of 60 years, a rapid increase in the incidence of distal femoral fractures was observed for both genders with a considerable female predominance. There are several surgical technique approaches on distal femur fracture. The surgical approach selection on distal femur fracture depends on classification of fracture type, the surgeon's capability, implant availability, facilities and infrastructure. For type c distal femur fracture that require lateral and medial exposure, mediana / medial parapatellar straight approach can be performed with a lateral parapatellar incision to dislocate the patella medially.
\end{abstract}

Keywords: Distal Femur Fracture, Surgical Approach, Surgical Incision, Mediana approach, Type c fracture

\section{INTRODUCTION}

Distal Femur fractures are rare, with the literature reporting a prevalence of $0.5 \%$ of all fractures. Incidence rates of distal femur fractures have only been reported in a small number of studies. Fractures of the distal femur is described as a classic fragility fracture, with the mean age of patients reported as 67.3 years and the vast majority of fractures $(83 \%)$ occurring in women.

A study shows an incidence of distal femur fractures is $8.7 / 100,000 /$ year. After the age of 60 years, a rapid increase in the incidence of distal femoral fractures was observed for both genderswith a considerable female predominance. Nowdays, the surgical management of distal femur fracture is evolving. This review will discuss about the incision approach on distal femur approaches.

\section{Distal Femur Fracture Classification}

According to Muller et al, distal femur fracture classified into 3 types, type $\mathrm{A}$ as extra-articular fracture which divided into 3 subtypes (A1 simple extra-articular fracture that include apophyseal, metaphyseal oblique or spiral and transverse type; A2 metaphyseal wedge extra-articular fracture that include intact, fragmented and lateral, fragmented and medial; A3 metaphyseal complex extraarticular fracture), type B as partial articular fracture which also divided into 3 subtypes (B1 partial articular fracture, lateral condyle, sagittal; B2 partial articular fracture, medial condyle, sagittal; B3 partial articular fracture, frontal), and type $\mathrm{C}$ as complete articular fracture divided into 3 subtypes ( $\mathrm{C} 1$ complete articular fracture, anterior simple, metaphyseal simple; C2 complex articular fracture, articular simple, metaphyseal multifragmentary; C3 complete articular fracture, multifragmentary). 


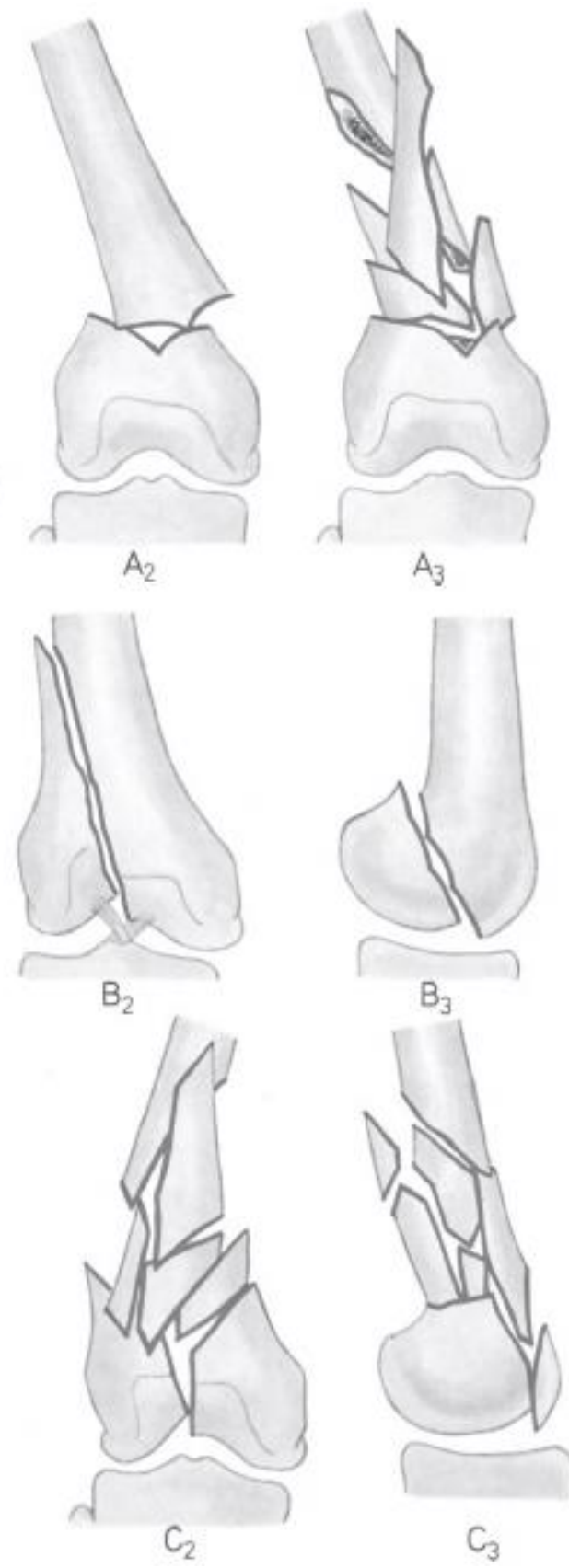



$\mathrm{B}_{3}$

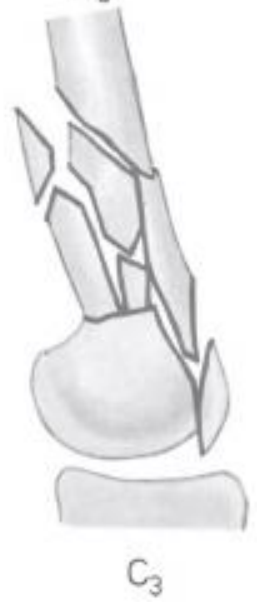

Figure 1. Classification of distal femur types ${ }^{6}$

\section{Surgical Insision Technique Approach}

Distal femur fractures can be operatively treated through minimally invasive submuscular techniques involving small lateral incisions or through conventional exposures performed anteriorly, laterally, or medially based on the fracture pattern and surgeon comfort $^{7,8}$.

Based on those distal femur fracture classification, if an operation is indicated, requiring surgical technique approach which according to Stanley Hoppenfeld is divided into :
a. Lateral approach
b. Posterolateral approach
c. Anterolateral approach
d. Anteromedial approach
e. Posterior approach

The workhorse approach proven in fractures involving the articular surface is the lateral para-patellar arthrotomy with varying degrees of proximal extension ${ }^{9}$. The swashbuckler and mini swashbuckler 
approaches have been described, enumerating techniques to extend the laterally based arthrotomy proximally between the IT band and vastus lateralis by following the lateral intermuscular septum to expose the distal femur ${ }^{10,11}$. However, mediana or medial parapatella incision for distal femur fracture type $\mathrm{C}$ is admissible to be done to attain exposure to the lateral and medial condyles of the distal femur both extra-articular and intraarticular, either $\mathrm{T}$ or $\mathrm{Y}$ comminuted fractures or severe comminutive.

\section{Lateral Approach}

The uses of the lateral approach include the following :

a. Open reduction and internal fixation of intertrochanteric fractures (this is by far the most common use of the approach)

b. Insertion of internal fixation in the treatment of subcapital fractures or slipped upper femoral epiphysis

c. Subtrochanteric or intertrochanteric osteotomy d. Open reduction and internal fixation of femoral shaft fractures, subtrochanteric fractures, and supracondylar fractures of the femur

e. Extra-articular arthrodesis of the hip joint

f. Treatment of chronic osteomyelitis of the femur

g. Biopsy and treatment of bone tumors

The minimally invasive approach to the distal femur utilizes two windows. The distal window is in effect a lateral parapatellar approach to the knee and allows visualization of the articular surface of the distal femur. The proximal window provides access to the femoral shaft and is a portion of the lateral approach to the femoral shaft. The minimally invasive approach is indicated for open reduction and internal fixation of distal femoral fractures, especially those that involve intra-articular fractures associated with complex metaphyseal injuries

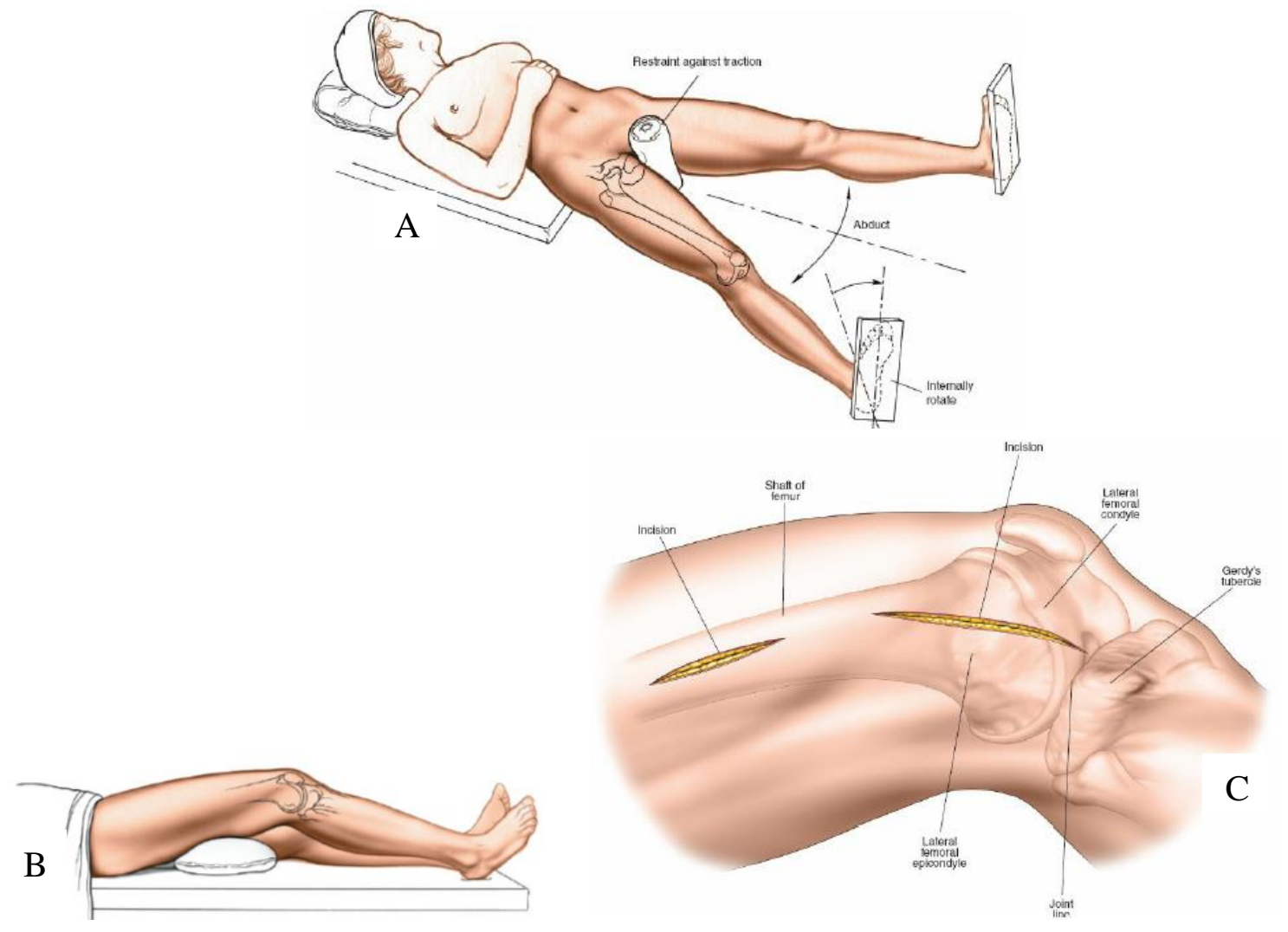

Figure 2. A. Position of patients on lateral approach. B.Position of patients on minimally invasive lateral approach. C.Incision of minimally invasive lateral approach. 


\section{Posterolateral Approach}

The uses of the posterolateral approach include the following :

a. Open reduction and plating of femoral fractures, especially supracondylar fractures

b. Open intramedullary nail placement for femoral shaft fractures if facilities for closed nailing do not exist

c. Treatment of nonunion of femoral fractures d. Femoral osteotomy (which is performed rarely in the region of the femoral shaft)

e. Treatment of chronic or acute osteomyelitis

f. Biopsy and treatment of bone tumors

The extended of this approach allows accurate visualization of the entire distal end of the femur. This extension is used to allow reduction and fixation of intra-articular fractures of the distal femur.

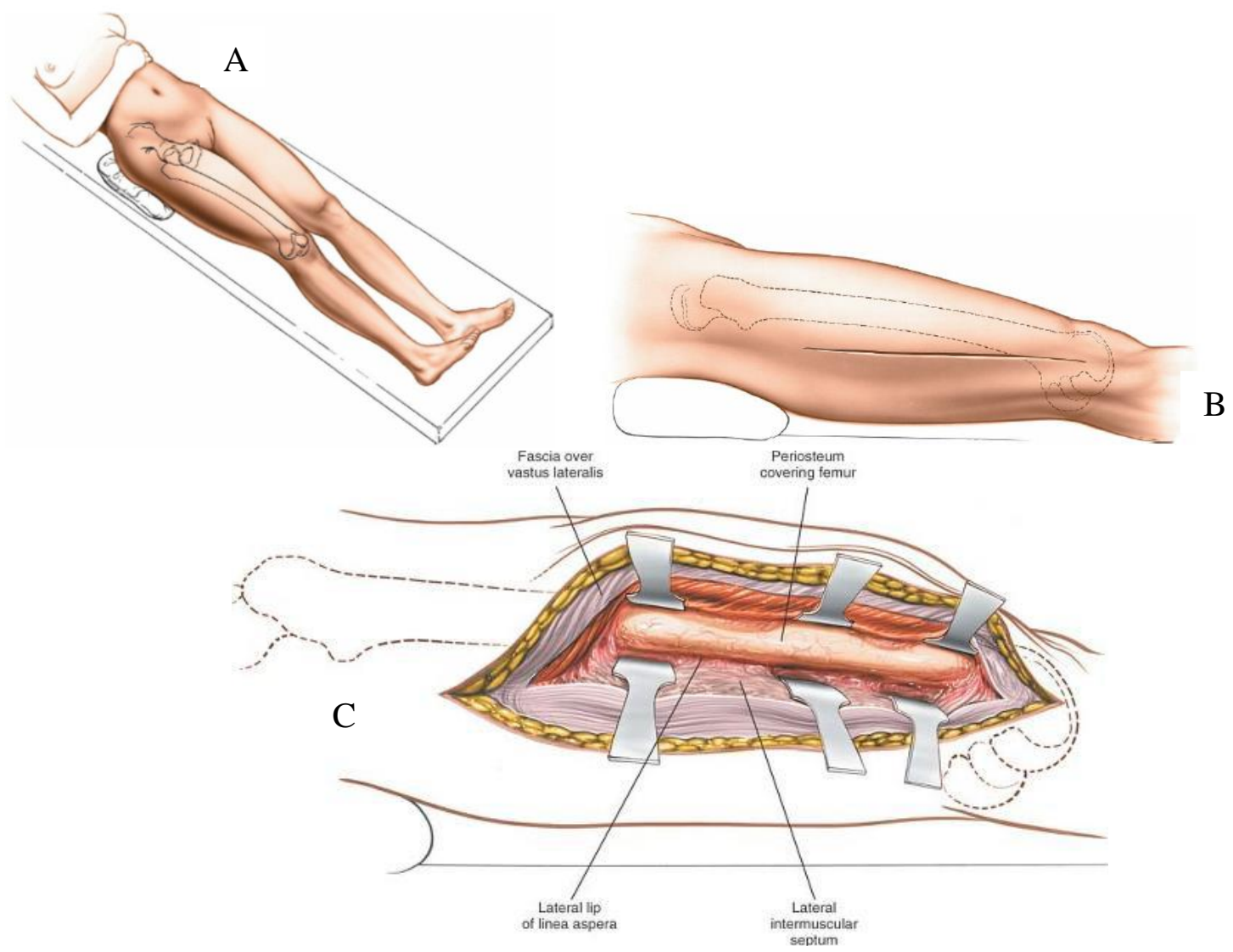

Figure 3. A. Position of patients. B. Incision of posterolateral approach. C.Exposure of extended approach

\section{Anterolateral Approach}

The anterolaeral approach can expose the entire femoral shaft. Its uses include the following :

a. Open reduction of femoral fractures and internal fixation with either plates or intramedullary rods

b. Treatment of non-union of femoral fractures

c. Femoral osteotomy (rarely performed in the region of the femoral shaft)

d. Treatment of chronic osteomyelitis e. Biopsy and treatment of bone tumors

f. Quadricepsplasty

\section{Anteromedial Approach}

The anteromedial approach provides an excellent view of the lower two-thirds of the femur and the knee joint. Its uses include the following :

a. Open reduction and internal fixation of fractures of the distal femur, particularly those that extend into the knee joint and 
require medial buttress plating (its major use)

b. Open reduction and internal fixation of femoral shaft fractures c. Treatment of chronic osteomyelitis

d. Biopsy and treatment of bone tumors

e. Quadricepsplasty

f. Distal femoral osteotomy

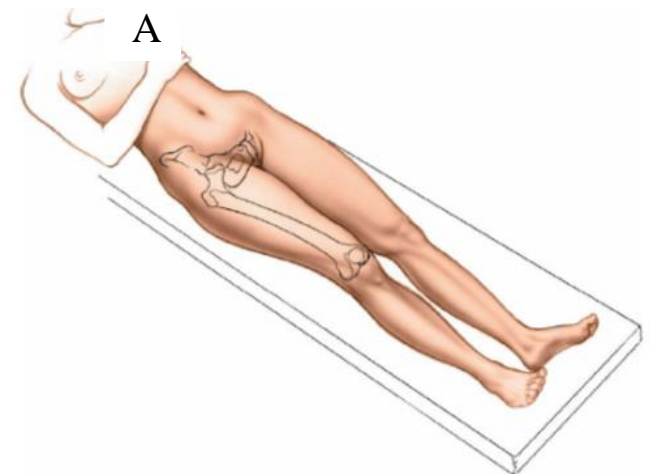

Figure 4. A. Position of patients. B. Incision of anteromedial approach ${ }^{8}$

\section{Posterior Approach}

The posterior approach is useful in patients who cannot undergo more anterior approaches because of local skin problems. It provides access to the middle three-fifths of the bone, as well as to the sciatic nerve. Although it is performed rarely, its uses include the following:

a. Treatment of infected cases of nonunion of the femur

b. Treatment of chronic osteomyelitis

c. Biopsy and treatment of bone tumors

d. Exploration of the sciatic nerve

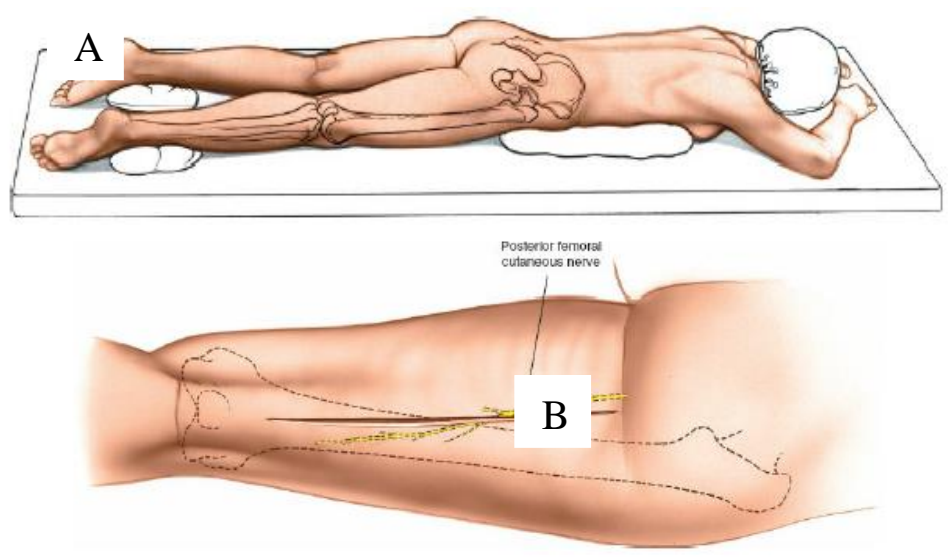

Figure 4. A. Position of patients. B. Incision of posterior approach.

\section{Medial Parapatella Approach}

The medial parapatellar approach is the workhorse approach to the knee. Extended to its full length, it allows excellent access to most structures. The uses of the medial parapatellar approach include the following: a. Total knee replacement

b. Synovectomy

c. Ligamentous reconstructions

d. Patellectomy

e. Drainage of the knee joint in cases of sepsis

f. Open reduction and internal fixation of distal femoral fractures when a medial plate is to be used 

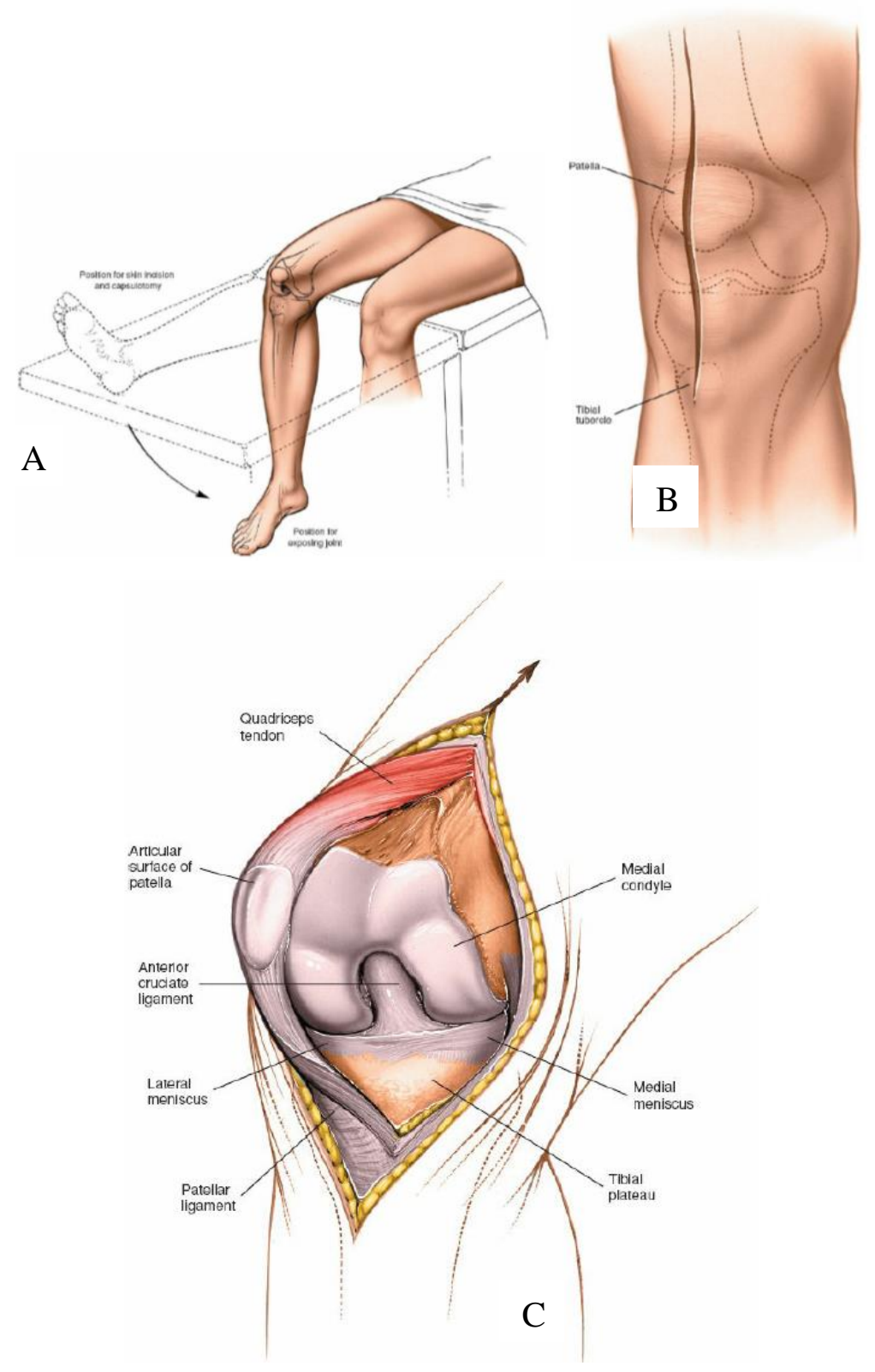

Figure 3. A. Position of patients. B. Incision of medial parapatella approach. C.Exposure of condyle 
Table 1. Surgical Incision Technique Approach on Distal Femur Fracture

\begin{tabular}{|c|c|c|c|c|c|c|c|c|c|c|}
\hline Approach & Commonly Used & Uses Include & $\begin{array}{c}\text { Position of } \\
\text { patient }\end{array}$ & Landmark & Incision & $\begin{array}{l}\text { Internervous } \\
\text { plane }\end{array}$ & $\begin{array}{c}\text { Superficial } \\
\text { Surgical } \\
\text { Dissection }\end{array}$ & $\begin{array}{l}\text { Deep Surgical } \\
\text { Dissection }\end{array}$ & Dangers & Enlarge \\
\hline Lateral & $\begin{array}{l}\text { Upper third of } \\
\text { femur }\end{array}$ & $\begin{array}{l}\text { ORIF distal femur } \\
\text { extended }\end{array}$ & $\begin{array}{l}\text { Prox : supine } \\
\text { Shaft : Lateral } \\
\text { Distal : supine }\end{array}$ & \begin{tabular}{|l} 
Greater \\
trochanter - \\
shaft femur
\end{tabular} & $\begin{array}{l}\text { Longitudinal begin } \\
\text { midde greater } \\
\text { trochanter }\end{array}$ & No & Fascia lata & $\begin{array}{l}\text {-Vastus lateralis } \\
\text {-Femoral shaft }\end{array}$ & A.perforantes & $\begin{array}{l}\text {-Proximal } \\
\text {-Distal }\end{array}$ \\
\hline Posterolateral & $\begin{array}{l}\text { Entire length of } \\
\text { femur }\end{array}$ & $\begin{array}{l}\text { ORIF suracondyler } \\
\text { femur }\end{array}$ & Supine & $\begin{array}{l}\text { Latera femoral } \\
\text { epicondyle }\end{array}$ & $\begin{array}{l}\text { Longitudinal } \\
\text { posterolateral }\end{array}$ & $\begin{array}{l}\text { Vastus lateral } \\
\text { (femoral nerve) } \\
\text { Lateral } \\
\text { (Intermuscular) } \\
\text { Septum (sciatic } \\
\text { nerve) } \\
\end{array}$ & $\begin{array}{l}\text { Deep fascia } \\
\text { (fascia lata) }\end{array}$ & $\begin{array}{l}\text {-Vastus lateralis } \\
\text {-Lateral intermuscular } \\
\text { septum }\end{array}$ & A.perforantes & $\begin{array}{l}\text {-Proximal } \\
\text {-Distal }\end{array}$ \\
\hline Anterolateral & $\begin{array}{l}\text { Expose entrie } \\
\text { femoral shaft }\end{array}$ & $\begin{array}{l}\text { Expose knee joint } \\
\text { intraarticular fracture } \\
\text { extended }\end{array}$ & Supine & $\begin{array}{l}\text {-Anterior } \\
\text { Superior Iliac } \\
\text { Spine } \\
\text {-Lateral border } \\
\text { patella }\end{array}$ & $\begin{array}{l}5 \mathrm{~cm} \text { below ASIS } \\
\text { to lateral border } \\
\text { patella }\end{array}$ & No & $\begin{array}{l}\text { Fascia lata-vastus } \\
\text { lateral and rectus } \\
\text { femoris }\end{array}$ & $\begin{array}{l}\text {-Distal femur bone } \\
\text {-Vastus intermedialis } \\
\text {-Femoral shaft }\end{array}$ & $\begin{array}{l}\text {-nerve to vastus } \\
\text { lateralis } \\
\text {-branch of } \\
\text { a.circumflexa } \\
\text { femoris } \\
\text {-vastus } \\
\text { intermedialis } \\
\text { adhession } \\
\end{array}$ & $\begin{array}{l}\text {-Proximal } \\
\text {-Distal }\end{array}$ \\
\hline Anteromedial & $\begin{array}{l}\text { Lower two thirds of } \\
\text { femur and knee }\end{array}$ & $\begin{array}{l}\text { ORIF distal femur } \\
\text { and knee }\end{array}$ & Supine & Vastus medialis & $\begin{array}{l}10-15 \mathrm{~cm} \\
\text { longitudinal }\end{array}$ & No & $\begin{array}{l}\text { Fascia lata-vastus } \\
\text { medialis and } \\
\text { rectus femoris }\end{array}$ & $\begin{array}{l}\text {-Capsule knee joint } \\
\text {-Quadriceps tendon } \\
\text {-Vastus intermedialis } \\
\text {-Femoral distal bone }\end{array}$ & $\begin{array}{l}\text {-Medial superior } \\
\text { genicular artery } \\
\text {-vastus medialis } \\
\text { (Patella } \\
\text { subluxation) }\end{array}$ & $\begin{array}{l}\text {-Proximal } \\
\text {-Distal } \rightarrow \text { Patella } \\
\text { subluxation } \\
\text {-Lateral }\end{array}$ \\
\hline Posterior & $\begin{array}{l}\text { If cannot undergo } \\
\text { more anterior } \\
\text { approach because } \\
\text { of local skin } \\
\text { problem }\end{array}$ & $\begin{array}{l}\text {-Osteomyelitis } \\
\text {-Bone tumors } \\
\text {-Exploration of the } \\
\text { sciatic nerve }\end{array}$ & Prone & Gluteal folds & $\begin{array}{l}\text { Longitudinal } \pm 20 \\
\text { cm long down the } \\
\text { midline of the } \\
\text { posterior aspect of } \\
\text { the thigh }\end{array}$ & $\begin{array}{l}\text { Lateral } \\
\text { (intermuscular) } \\
\text { Spetum (femur } \\
\text { nerve) } \\
\text { Biceps femoris } \\
\text { (sciatic nerve) }\end{array}$ & $\begin{array}{l}\text {-Deep fascia of } \\
\text { thigh } \\
\text {-Posterior } \\
\text { femoral } \\
\text { cutaneous nerve } \\
\text {-Biceps femoris }\end{array}$ & $\begin{array}{l}\text {-Long head biceps } \\
\text {-Femoris medialis } \\
\text {-Lateral intermuscular } \\
\text { septum laterally } \\
\text {-Short head } \\
\text { biceps } \rightarrow \text { detach from } \\
\text { femur }\end{array}$ & $\begin{array}{l}\text {-sciatic nerve and } \\
\text { branches to } \\
\text { biceps femoris }\end{array}$ & Cannot \\
\hline
\end{tabular}




\begin{tabular}{|c|c|c|c|c|c|c|c|c|c|c|}
\hline $\begin{array}{l}\text { Mediana } \\
\text { (Medial } \\
\text { Parapatellar } \\
\text { Approach) }\end{array}$ & $\begin{array}{l}\text { Workhouse } \\
\text { approach to the } \\
\text { knee }\end{array}$ & $\begin{array}{l}\text { Distal femur } \\
\text { (repair ACL) }\end{array}$ & Supine & $\begin{array}{l}\text { Patella - tibial } \\
\text { tubercle }\end{array}$ & \begin{tabular}{|l|}
$3-5 \mathrm{~cm}$ above \\
the superior \\
pole of the \\
patella run \\
distally: \\
1. medial \\
corner and \\
around medial \\
border patella \\
running toward \\
and just medial \\
patella \\
ligament \\
(curve) \\
2.Straight \\
midline to tibia \\
tubercle
\end{tabular} & No & $\begin{array}{l}\text {-Joint capsule } \\
\text {-Patellar } \\
\text { ligament } \\
\text {-Quadriceps } \\
\text { tendon } \\
\text {-Synovillus } \\
\text {-Medial } \\
\text { meniscus }\end{array}$ & $\begin{array}{l}\text {-Sciatic nerve } \\
\text {-Posterior aspect } \\
\text { femur } \\
\text {-Bone patella } \\
\text {-Distal femur } \\
\text {-Proximal tibia }\end{array}$ & $\begin{array}{l}\text {-Inferior } \\
\text { paella nerve } \\
\text {-Patellar } \\
\text { ligament }\end{array}$ & $\begin{array}{l}\text {-Proximal } \\
\text {-Distal } \rightarrow \\
\text { Patella } \\
\text { subluxation }\end{array}$ \\
\hline
\end{tabular}




\section{Surgical Incision Approach And Types Of Distal Femur Fracture}

There are several types of surgical technique approaches on distal femur fracture. Opting

which technique to apply according to the abilities and habits of a surgeon, classification or type of fracture of the distal femur and the availability of the facilities and infrastructure ${ }^{13}$.

Based on surgical approach, distal femur fracture classification, and implant option of open reposition and internal fixation, then surgical approach on distal femur fracture is divided into ${ }^{13}$ :

a. If type A fracture (extra-articular)

- Simple or non - avulsion comminutive can be done posterolateral approach

- Avulsion or severe comminutive that needs lateral and medial side exposure for reposition, can be done mediana/medial parapatellar approach

- If avulsion fracture of medial side can be done anteromedial approach

b. If type B fracture (partial articular)

- If it is a lateral or sagittal fracture, can be done posterolateral approach

- If it is medial or sagittal fracture, can be done posteromedial approach

- If it is posterior or frontal fracture, can be done posterior approach

c. If type $\mathrm{C}$ fracture (complete articular fracture)

Bicondylar type $\mathrm{C}$ fracture requires a proper lateromedial exposure, and a stable internal fixation using plate and screw which commonly put on lateral side. Therefore, it needs a straight mediana/medial parapatellar surgical approach and the patella is dislocated medially for lateral and medial, proximal and distal repositioning along with a plate and screw fixation of lateral side of distal femur.

\section{CONCLUSION}

a. There are several surgical technique approaches on distal femur fracture

b. The surgical approach selection on distal femur fracture depends on classification of fracture type, the surgeon's capability, implant availability, facilities and infrastructure. c. For type c distal femur fracture that require lateral and medial exposure, mediana / medial parapatellar straight approach can be performed with a lateral parapatellar incision to dislocate the patella medially.

\section{REFERENCES}

1. A. C. Ng,M. T. Drake, B.L.Clarke SAS. Trends in subtrochanteric, diaphyseal, and distal femur fractures. Bone. 2014;23(1):1-7. doi:10.1007/s00198-0111777-9.Trends

2. Streubel PN. Mortality after periprosthetic femur fractures. $J$ Knee Surg. 2013;26(1):27-30. doi:10.1055/s0033-1333905

3. Pietu G, Lebaron M, Flecher X, Hulet C, Vandenbussche E. Epidemiology of distal femur fractures in France in 2011-12. Orthop Traumatol Surg Res. 2014;100(5):545-548. doi:10.1016/j.otsr.2014.06.004

4. Norris GR, Checketts JX, Scott JT, Vassar M, Norris BL, Giannoudis P V. Prevalence of Deep Surgical Site Infection After Repair of Periarticular Knee Fractures: A Systematic Review and Meta-analysis. JAMA Netw open. 2019;2(8):e199951.

doi:10.1001/jamanetworkopen.2019.9951

5. Elsoe R, Ceccotti AA, Larsen P. Population-based epidemiology and incidence of distal femur fractures. Int Orthop. 2018;42(1):191-196. doi:10.1007/s00264-017-3665-1

6. M. E. Muller MA, Willenegger RSH. Manual of INTERNAL FIXATION Techniques Recommended by the AOASIF Group. Vol 53. 3rd Editio. Springer -Verlag; 1992. http://www.elsevier.com/locate/scp

7. Von Keudell A, Shoji K, Nasr M, Lucas R, Dolan R, Weaver MJ. Treatment options for distal femur fractures. $J$ Orthop Trauma. 2016;30(8):S25-S27. doi:10.1097/BOT.0000000000000621

8. Stanley Hoppenfeld, Piet de Boer RB. Surgical Exposures In Orthopaedics : The Anatomic Approach. Vol 53. 5th Editio. Wolters Kluwer; 2017.

9. Bin Z, Song L, Binghua W, Ping Q, Min D. A new anterolateral approach for type C fractures of the distal femur. Int Surg. 
2014;99(6):875-879. doi:10.9738/INTSURG-D-14-00062.1

10. Beltran MJ, Blair JA, Huh J, Kirby JM, Hsu JR. Articular exposure with the swashbuckler versus a "miniswashbuckler" approach. Injury. 2013;44(2):189-193.

doi:10.1016/j.injury.2012.10.021

11. Beltran MJ, Gary JL, Collinge CA. Management of distal femur fractures with modern plates and nails: State of the art. J Orthop Trauma. 2015;29(4):165172. doi:10.1097/BOT.0000000000000302

12. Ehlinger M, Ducrot G, Adam P, Bonnomet F. Distal femur fractures.
Surgical techniques and a review of the literature. Orthop Traumatol Surg Res. 2013;99(3):353-360.

doi:10.1016/j.otsr.2012.10.014

13. S.Terry Canale, James H.Beaty FMA. CAMPBELL'S OPERATIVE

THIRTEENTH EDITION

ORTHOPAEDICS. Vol 71. Elsevier; 2017. doi:10.2106/00004623-19897104000026

14. Hake ME, Davis ME, Perdue AM, Goulet JA. Modern Implant Options for the Treatment of Distal Femur Fractures. $J$ Am Acad Orthop Surg. 2019;27(19):E867-E875. doi:10.5435/JAAOS-D-17-00706 